\title{
NUTRITIONAL STUDIES ON COMPENSATORY GROWTH PHENOMENON IN FATTENING BUFFALO CALVES
}

\author{
M. R. M. Mostafa, A. A. Abdou, M.A. El Shora, Y.H. Hafez, A.M. Sakr, A.F.I. Abdel Latif \\ and A.A. El-Giziry \\ Animal Production Research Institute, Agricultural Research Centre, Dokki, Giza, Egypt.
}

(Received 5/5/2019, accepted 26/6/2019)

\section{SUMMARY}

$\mathrm{T}$

This study was conducted to investigated the effects of feed restriction at early age and re-alimentation (compensatory growth phenomenon) on growth and fattening buffalo calves performance. Twenty four buffalo calves with an average $123 \pm 1.05 \mathrm{Kg}$ live body weight (LBW) and aged six months old were used in a feeding trial lasted for ( 150 - days) as restricted feeding period followed by (90- days) as re-alimentation period using randomized complete block design. Animals were divided into four similar groups (six calves per group) according to their LBW. During the feed restriction period, all animals' groups were fed the roughage portion (50\% corn silage, $40 \%$ ammoniated - treated rice straw and $10 \%$ berseem hay) at the ad libitum level with supplementation of concentrate feed mixture (CFM) at the levels of $1.5 \%$ (T1) as control, $1 \%$ (T2), 0.5 (T3) and $0.00 \%$ (T4) as tested rations, based on their (LBW). Following, the restriction period, all calves were fed on $2.5 \%$ CFM of their LBW plus $1 \%$ ammoniated treated rice straw (TRS) over realimentation period. In the restricted feed period, results indicated that most of nutrient digestibilities were significantly $(\mathrm{P}<0.05)$ lower with the restricted rations $(\mathrm{T} 2, \mathrm{~T} 3$ and $\mathrm{T} 4)$ than those of control group (T1). Vice versa trend was associated with CF digestibility among the dietary treatments. The feeding values as TDN, DCP and DE were followed comparable trends to those of nutrient digestibilities among treatments. Also, the DMI of calves fed restricted $(\mathrm{T} 3$ and $\mathrm{T} 4)$ rations were significantly $(\mathrm{P}<0.05)$ lower than those calves fed restricted rations (T2) and unrestricted ration (T1). Daily gain was decreased significantly $(\mathrm{P}<0.05)$ with calves restricted feed rations (T3 and $\mathrm{T} 4$ ) than those of the restricted ration (T2) and control groups (T1), but no significantly difference was found between $\mathrm{T} 1$ and $\mathrm{T} 2$ in this item. Likewise, feed conversion (as $\mathrm{Kg} \mathrm{DM}$ or TDN $/ \mathrm{kg}$ gain) was decreased significantly $(\mathrm{P}<0.05)$ with all calves fed restricted $(\mathrm{T} 2, \mathrm{~T} 3$ and $\mathrm{T} 4)$ rations compared with nonrestricted (T1). Blood serum total protein and albumin concentrations were significant lower $(\mathrm{P}<0.05)$ for all restricted rations than that of control one. During re-alimentation period, results indicated that calves fed restricted rations (T2, T3 and T4) consumed significant lower DMI and achieved significant higher daily gain in comparison with those of unrestricted group (T1). Also, feed conversion ratio was significantly better with restricted groups vs. the unrestricted one (control). Over the whole experimental period (240 - days), DM intake of calves fed restricted rations (T2, T3 and $\mathrm{T} 4)$ were significantly $(\mathrm{P}<0.05)$ lower than that of non-restricted $(\mathrm{T} 1)$. Average daily gain of calves fed unrestricted rations (T1) and restricted ration (T2) were significantly $(\mathrm{P}<0.05)$ higher than those of restricted rations (T3 and T4). Calves fed restricted ration (T2) was significantly $(\mathrm{P}<0.05)$ better in feed conversion than those of the restricted rations (T3 and T4) and control one (T1). The improvement of economic efficiency based on control ration (100\%) were 108.19, 113.31 and $125.26 \% \%$ for the tested rations (T2, T3 and T4), respectively. Based on this study, results indicated that all calves fed restricted rations (T2, T3 and T4) in re-alimented period gave significant better growth performance, daily gain and feed conversion ratio over the re-alimented period, being incidencing the compensatory phenomenon which led to potential positive effect on economical efficiency over the whole period of fattening calves.

Keywords: Fattening buffalo calves, feed restriction and re-alimentation, growth performance and economic efficiency.

\section{INTRODUCTION}

The feeding regimen is play an important role in beef production management where many feeding systems and models were established according to the prevailing natural resources and socio - economical conditions of a region. In Egypt, the acute shortage in feed resources particularly in summer season may be partially alleviated through the following some more efficiency feeding systems for specifically growing fattening cattle (Mostafa et al., 1993). The important nutritional factors that significantly affect on beef cattle performance and its carcass and meat quality are energy and protein levels in diets, its sources and intake, roughage concentrate ratio, vitamins, minerals, additives as well as the feeding and production systems. One 
of the most suitable feeding system used for meat production operation in Egypt that dependable on feeding weaned calves over approximately 6- months on berseem forage alone or with little amount of concentrate feed mixture, followed by about 5- months on dry high energy ration as finishing period. Earlier, Ainsile et al. (1992) reported that calves can be successfully fed on high amount of forage during the growing period then switched into higher concentrate with low forage diet for finishing period. Furthermore, Hanafy (1998) fed steer on $0.5 \%$ of their body weight concentrates with basal ration of berseem in comparison with those given 0.75 or $1 \%$ concentrate, the author found that restriction in concentrate group (0.5\%) gave better growth and feed utilization during finishing phase with the lowest feed cost / kg gain. Similarly with sheep, Blackburn et al. (1991) and Allen et al. (1996) indicated that additional profits can be obtained by grazing lambs on high - quality pasture before switched on the feedlot phase. Recently, Abouheif et al. (2013) concluded that when integrating the feed restriction strategies into feeding management practices, the complimentary effects of compensatory growth improve feed efficiency and reduce carcass fatness without altering the final live body weight of lambs. In addition the production of leaner carcass, which meat a healthier option to the consumers demand and the concomitant reduction of feeding costs may overcome the probable drop in carcass grade value. It would be appreciated by both consumer and sheep producer and can thus be adapted as a nutritional practice for growing - finishing lambs. Additionally with goats kids, realimentation after $75-\mathrm{d}$ feed restriction was associated with a greater daily gain and less internal fat, in corresponding of unrestricted kids (Dashtizadeh et al. 2008). The little knowledge, in particular with buffaloes calves of modulator effects of feed restriction at early age followed by re-alimentation period (at finishing phase) were undertake to study such effects on compensatory growth, nutritional utilization efficiency and economical of experimental feeding system.

Therefore, the present study aimed to investigate the effects of feed restriction and re-alimentation (compensatory growth) on growing and fattening buffalo calves performance.

\section{MATERIALS AND METHODS}

This research work was carried out at Mehalet Mousa Research Station, that belonging to Animal Production Research Institute, Agriculture Research Center, Ministry of Agriculture, Kafr El Shiekh Governorate, Egypt.

\section{Animals and rations:}

Twenty four buffalo calves with an average $123 \pm 1.05 \mathrm{Kg}$ live body weight and aged five months old were used in a feeding trial lasted for (150 - days) as restricted feeding period followed by (90- days) as realimentation period using randomized complete block design. The experimental animals were divided into four similar groups (six calves per group) according to their live body weight. During the restricted period (growing phase), all animals' groups were fed the roughage portion at the ad libitum (50\% corn silage, $40 \%$ ammoniated - treated rice straw (TRS) and $10 \%$ berseem hay $(\mathrm{BH})$ at the ad libitum with supplementation of concentrate feed mixture (CFM) at rate of $1.5 \%$ (T1) as control, $1 \%$ (T2), 0.5 (T3) and $0.0 \%$ (T4) respectively, based on their body weight (LBW). Following, the restriction period, all calves were fed on $2.5 \%$ CFM of their LBW plus $1 \%$ ammoniated treated rice straw (TRS) as a roughage portion over realimentation period (finishing phase). The pelleting CFM was consisted of 38\% yellow corn, 32\% undecorticated cotton seed, $25 \%$ wheat bran, $3 \%$ molasses, $1 \%$ limestone and $1 \%$ common salt. The chemical composition of the feed ingredients of the experimental rations and calculated chemical composition of the experimental rations during restriction and re-alimentation periods are present in Table (1). The experimental rations were offered twice daily (at 8 am and $3 \mathrm{pm}$ ) and fresh water was allowed freely. All animals were vaccinated and managed in accordance of the established daily routine of the livestock and they injected with vitamins AD3E to cover their requirements. The experimental animals were weighted at the beginning of the experimental and then biweekly intervals along the experiment. The body weight changes and daily gain were recorded for each animal. Economical efficiency was expressed as the ratio between the cost of output (weigh gain) and the cost of input (feed consumed) where, feed cost was based on the current price (LE/ton) of CFM, CS, TRS and BH as 3500, 550, 320 and 1250 L.E., respectively. In addition, the price of live body weight was $55 \mathrm{LE} / \mathrm{kg}$.

\section{Digestibility trials:}

Four digestibility trials were conducted with three buffalo calves chosen randomly from each group during the restricted feed period, to determine the digestibility and feeding values of experimental rations. 
Also, one digestibility trial was conducted during re-alimentation period to determine the digestibility and feeding values of finishing ration using three calves chosen from the animals of this period. Acid insoluble Ash (AIA) as a natural marker as described by (Van Keulen and Young, 1977) was employed. Fecal grab samples of about $300 \mathrm{~g}$ were collected from the rectum twice daily over 5- day at the end of the feeding trial period. Blood samples were collected from all animals at the end of digestibility trials before morning feeding from the jugular vein and these samples were immediately centrifuged at $4000 \mathrm{rpm}$ for 20 minutes. Blood serum was separated and stored at $-250 \mathrm{C}$ until analysis.

\section{Laboratorial analysis:}

The chemical analysis of representative samples of feed and feces were analyzed according to (AOAC, 2000). Blood serum was separated from the whole blood to determine some blood serum parameters using commercial kits of Bio-Merieus, lab, France, following the same steps described by manufactories as the total protein, according to Armstrong and Carr (1964), albumin was analysed according to Doumas (1971) and globulin was calculated by subtracting the albumin value from total protein. The activities of aspartate aminotransferase (AST) and alanine aminotransferase (ALT) were analysed according to Reitman and Frankal (1957).

\section{Statistical analysis:}

Statistical analysis was carried out by General Linear Model procedures (GLM) described in SAS User's Guide (SAS, 2003). Differences among treatment means were separated by Duncan's new multiple-range test (Duncan, 1955).

\section{RESULTS AND DISCUSSION}

\section{Chemical composition of ingredients and rations:}

Chemical composition of ingredients and calculated experimental rations fed to calves during the restricted and re-alimentation periods are presented in Table (1). These data revealed that the chemical composition of concentrate feed mixture (CFM), corn silage (CS), berseem hay (BH), ammoniated rice straw (TRS) and calculated composition of experimental rations are within the normal ranges published by

Table (1): Chemical composition of feed ingredients and calculated chemical composition of rations (\% on DM basis) through the feed restriction and re-alimentation periods.

\begin{tabular}{lccccccc}
\hline Feedstuff & \multicolumn{7}{c}{ Chemical composition \% } \\
\cline { 2 - 8 } & DM & OM & CP & CF & EE & Ash & NFE \\
\hline CFM* & 90.38 & 88.92 & 15.83 & 13.12 & 2.68 & 11.08 & 57.29 \\
Corn silage & 30.36 & 90.98 & 7.43 & 33.31 & 1.10 & 9.02 & 49.14 \\
Berseem hay & 91.30 & 86.82 & 13.93 & 35.95 & 2.59 & 13.18 & 34.35 \\
Ammoniated R..S.* & 89.63 & 81.18 & 6.32 & 36.47 & 1.31 & 18.82 & 37.08 \\
Calculated experimental rations during feed restriction period: & & & & \\
T1 & 72.63 & 88.10 & 11.65 & 24.52 & 1.98 & 11.90 & 49.95 \\
T2 & 68.57 & 87.55 & 10.25 & 28.02 & 1.76 & 12.45 & 47.53 \\
T3 & 62.47 & 87.40 & 8.96 & 31.33 & 1.53 & 12.60 & 45.58 \\
T4 & 60.21 & 86.66 & 7.67 & 34.84 & 1.34 & 13.34 & 42.81 \\
Calculated experimental ration during feed re- alimentation period : & & & \\
Ration (All groups) & 90.18 & 86.86 & 13.30 & 19.34 & 2.31 & 13.14 & 51.91 \\
\hline *CFM; contained 38\% yellow corn, 32\% undecorticated cotton seed, 25\% wheat , 3\% molasses, 1\% limestone, 1\% \\
common salt.
\end{tabular}


Mostafa et al. (2015), Abou Elenin et al. (2016), Ghoniem, et al. (2017) and Abdou (2018). Also, data in Table 1 showed that DM, OM, CP, EE and NFE contents decreased and CF and ash contents increased with decreasing the levels of concentrate mixture in all restricted rations (T2, T3 and T4) than that of control ration (T1, unrestricted ration). The Results here are similar with those reported by (Mostafa et al., 1993, Gaafar et al., 2009, Mehrez et al., 2001 and El-Ashry et al., 2011 and Malisetty et al., 2014) who concluded that increasing CFM levels in the rations led to an increase in OM, CP and NFE contents with decrease CF content.

\section{Digestion coefficients and feeding values:}

Digestion coefficients and feeding values during the restricted and re-alimentation periods are presented in Table 2 and 3. During the restricted period, data showed that digestion coefficients of most nutrients were significantly $(\mathrm{P}<0.05)$ decreased with decreasing the levels of CFM in (T2, T3 and T4) restricted rations, except the CF digestibility that was significantly $(\mathrm{P}<0.05)$ increased in comparison with non-restricted ration (T1). These data are in harmony with those of Sayed (2009) who reported that nutrient digestibilities improved with increasing levels of energy in lambs diets. Furthermore, Gaafar et al. (2009) revealed that lactating buffaloes fed on two levels of concentrate : roughage ratio $(60: 40 \%)$ and $(40: 60 \%)$ with or without baker's yeast increased the digestibility of all nutrients with increasing CFM levels with or without yeast in their rations. Also, the results are in agreement with the findings of El-Ashry et al. (2011) who noticed that inclusion of different concentrate levels with corn silage for pregnant buffalo heifer diets had improved the digestibility of DM, OM, CP, EE and NFE\% with increasing the CFM in their rations which in turn led to an increase in degradability of protein and the flow rate of microbial nitrogen to the lower gut. With rabbits, during the restricted period Tumová et al. (2007) revealed that DM, CP and CF digestibilities of diets were significantly $(\mathrm{P}<0.05)$ higher with restricted feed than those fed ad libitum, but no significant differences were detected between restricted and non-restricted during the re-alimentation period. Also, Abdou (2011) stated that nutrient digestibilities increased with lower level of energy (80\%) than these with higher levels of energy (100 and 120\%) in ewes' diets. This might be attributed to increase rumen microbial activity and decreased DM intake for ewes fed lower level. Also, Steingass et al. (1994) decided that nutrient digestibilities decreased with increasing the feeding levels of concentrate. While, Singh et al. (2014) observed that the nutrient digestibilities not affected with decreasing levels of energy and protein in buffalo heifer diets compared with control one. Moreover, data in Table (2) showed that calves fed restricted rations (T3 and T4) recorded the lower digestion coefficients of most nutrients, this may be attributed, somewhat to their excessively CF in the rations than that with restricted ration (T2) and non restricted ration (T1).

Table (2): Nutrient digestibility of the experimental rations used through the feed restriction and re alimentation periods with buffalo calves.

\begin{tabular}{|c|c|c|c|c|c|c|}
\hline \multirow{2}{*}{$\begin{array}{l}\text { Exp. } \\
\text { Rations }\end{array}$} & \multicolumn{6}{|c|}{ Digestion coefficients (\%) } \\
\hline & $\mathrm{DM}$ & $\mathrm{OM}$ & $\mathrm{CP}$ & $\mathrm{EE}$ & $\mathrm{CF}$ & NFE \\
\hline \multicolumn{7}{|c|}{ Digestibility during feed restriction period: } \\
\hline $\mathrm{T} 1$ & $62.38^{\mathrm{a}} \pm 0.14$ & $67.16^{\mathrm{a}} \pm 0.28$ & $59.85 \mathrm{a} \pm 3.32$ & $76.70^{\mathrm{a}} \pm 1.10$ & $42.87^{\mathrm{c}} \pm 0.07$ & $80.47^{\mathrm{a}} \pm 1.07$ \\
\hline $\mathrm{T} 2$ & $61.48^{\mathrm{a}} \pm 0.30$ & $65.50^{\mathrm{b}} \pm 0.49$ & $57.70^{\mathrm{a}} \pm 0.88$ & $74.41^{\mathrm{b}} \pm 0.90$ & $46.72^{\mathrm{b}} \pm 1.31$ & $77.92^{\mathrm{b}} \pm 0.76$ \\
\hline $\mathrm{T} 3$ & $59.17^{\mathrm{b}} \pm 0.71$ & $63.51^{\mathrm{b}} \pm 0.59$ & $39.52^{\mathrm{b}} \pm 1.48$ & $65.19^{\mathrm{b}} \pm 0.96$ & $49.23^{\mathrm{a}} \pm 1.31$ & $78.92^{\mathrm{ab}} \pm 0.22$ \\
\hline $\mathrm{T} 4$ & $56.80^{\mathrm{c}} \pm 0.29$ & $60.62^{\mathrm{c}} \pm 0.01$ & $34.41^{\mathrm{b}} \pm 0.85$ & $63.24^{\mathrm{b}} \pm 2.98$ & $52.70^{\mathrm{a}} \pm 0.52$ & $71.67^{\mathrm{c}} \pm 0.39$ \\
\hline P. value & 0.0001 & 0.0001 & 0.0001 & 0.0012 & 0.0006 & 0.0001 \\
\hline \multicolumn{7}{|c|}{ Digestibility during feed re-alimentation period : } \\
\hline Rations $^{1}$ & 70.36 & 72.54 & 75.06 & 71.95 & 46.04 & 81.78 \\
\hline
\end{tabular}


Regarding the, feeding values of the experimental rations respecting TDN, DCP and DE\%, its values could be behaved comparable trends to those of nutrient digestibilities among the dietary treatments with the best values that were assured with control ration (T1) and the lowest ones were associated with the tested ration (T4). These results are in close agreement with those results of Sayed (2009), Gaafar et al. (2009), ElAshry et al. (2011) and Ali et al. (2014) who indicated that a markedly improvement in TDN and DCP values when increasing the level of CFM in the rations. In contrast, Singh et al. (2014) reported that the nutritive values as DCP and ME of buffalo heifers fed rations contained different levels of energy and protein were no affected.

Table (3): Feeding value of the experimental rations used through the feed restriction and re alimentation periods with buffalo calves.

\begin{tabular}{lccc}
\hline Exp. ration & \multicolumn{3}{c}{ Feeding values (\%) of the experimental rations } \\
\cline { 2 - 4 } & TDN & DCP & DE (Mcal/Kg DMI) \\
\hline During feed restriction period & $61.10^{\mathrm{a}} \pm 2.20$ & $6.97^{\mathrm{a}} \pm 0.39$ & $2.69^{\mathrm{a}} \pm 0.01$ \\
$\mathrm{~T} 1$ & $58.98^{\mathrm{b}} \pm 1.06$ & $5.91^{\mathrm{b}} \pm 0.08$ & $2.60^{\mathrm{b}} \pm 0.02$ \\
$\mathrm{~T} 2$ & $57.18^{\mathrm{b}} \pm 0.14$ & $3.54^{\mathrm{c}} \pm 0.13$ & $3.54^{\mathrm{c}} \pm 0.13$ \\
$\mathrm{~T} 3$ & $53.59^{\mathrm{c}} \pm 0.03$ & $2.64^{\mathrm{d}} \pm 0.07$ & $2.64^{\mathrm{d}} \pm 0.07$ \\
T4 & 0.0001 & 0.0001 & 0.0001 \\
P. value & & & \\
During feed re-alimentation period & 65.09 & 9.98 & 2.87 \\
Rations (All groups) & &
\end{tabular}

$a, b$ and $c:$ Means in the same Colum with different superscripts are significantly different at $(P<0.05$

\section{Productive performance:}

\section{During the restriction period:}

Results of feed intake, body weight gain and feed conversion during restricted period are presented in Table (4). The daily DM intake expressed as a percentage of BW or as metabolic body size, were slightly increased with most tested rations compared with control one, with only significant differences between T4 and each of $\mathrm{T} 3$ and control one (T1). On the other measurements, the daily feed intake that expressed as DM, TDN and DCP $(\mathrm{kg} / \mathrm{h})$ for calves fed restricted rations $(\mathrm{T} 2, \mathrm{~T} 3$ and $\mathrm{T} 4)$ were significantly $(\mathrm{P}<0.05)$ lower than that of non-restricted ration (T1). Moreover, among the fed restricted rations the best and highest value was occurred with restricted ones (T2). Similar results are recorded by Abdou (2011) who reported that the DMI increased with increasing energy levels in the ewes diets during pregnancy and lactation. Also, during the restricted period, Adeleye et al. (2011) found that DMI was significantly $(\mathrm{P}<0.05)$ higher with rams fed grass and concentrate supplement (control one) compared with rams fed grass alone for one month but non significant differences between rams fed control group or grass alone for two months. Moreover, Similar trend was observed with increasing the level of energy in the diets with heifer diets (Gaafar et al., 2009 and Neto et al., 2011), with growing lambs (Sowande et al., 2012, Malisetty et al., 2014, Abouheif et al., 2013 and Ali et al., 2014). In contrary, some workers indicated that feed intake was inversely related to level of energy in the diet (Hossain et al., 2003, Yagoub and Babiker, 2008 and Abbasi et al., 2012). Also, Sayed et al. (2009) indicated that feed intake was lower with lambs fed medium or higher energy rations than those fed on low energy ration. Whereas, some researchers showed no significant differences among dry matter intake and energy or protein levels of buffalo calves (Tauqir et al., 2011) or energy level with buffalo heifers (Anjum et al., 2013).

Results of the final body weight, total body gain and daily gain of calves fed the experimental rations during the restricted period 150 days are shown in Table (4). Data showed that the final boy weight, total 
body gain and average daily gain $(\mathrm{kg} / \mathrm{h})$ were significantly $(\mathrm{P}<0.05)$ decreased with calves fed $\mathrm{T} 3$ and $\mathrm{T} 4$ in compassion with $\mathrm{T} 1$ and $\mathrm{T} 2$, respectively. The average daily weight gain was $1.068,1.009,0.887$ and 0.806 $\mathrm{kg} / \mathrm{h}$ for T1, T2, T3 and T4, respectively. The lower rate of daily gain with calves fed on restricted rations was 5.52, 17.00 and $24.53 \%$ for restricted rations $\mathrm{T} 2 \mathrm{~T} 3$ and $\mathrm{T} 4$, respectively based on control ration (T1). Moreover, calves fed ration $\mathrm{T} 1$ followed by $\mathrm{T} 2$ recorded the highest $(\mathrm{P}<0.05)$ daily gain, while calves fed restricted ration T4 showed the lowest one. On the other hand, the reduce of daily gain with calves fed T4 and T3 rations might be attributed to decrease in dry matter intake and feed conversion. Moreover, All the pervious characteristics of the experimental rations, i.e. chemical composition, digestibility, feeding values and feed intake were closely reflected on the daily weight gain, which in turn decrease with decreasing the levels of concentrate mixture in the rations. These results are in close agreement with Tumová et al. (2002, 2003 and 2007) who explained that the poorest performances of rabbits fed restricted ration might be attributed to lower feed intake. Furthermore, Yakubu et al. (2007) and Dashtizadeh et al. (2008) reported that body weight gain decreased with decreasing energy and protein in rations of rabbits and goats and thereby resulting in not enough intake of nutrients required to sustain faster growth. Moreover, Neto et al. (2011) stated that daily gain of an animal could be reduced if any nutrient in the diets (especially energy and protein) is missing. Results of daily gain obtained in this study also corroborate with Adeleye et al. (2011) who indicated that the least daily gain was recorded with rams fed grass alone occurred (Panicum maximum) of ad libitum level for one month or two months than those fed control ration (P- maximum) at ad libitum level with concentrate supplement during restriction period. Sayed (2009) studied the effect of feeding different levels of energy (3.20, 3.50 and $3.90 \mathrm{Mcal} / \mathrm{kg}$ diet) with similar level of protein on lambs performance and found increasing in daily gain with increasing energy levels. Similarly, Sowande et al. (2012) reported that the higher daily gain was found with lambs fed diet consisting of forage and concentrate at ratio $25: 75 \%$ than those fed the other rations (50:50 and 75:25\%). Similar trend were observed by Anjum et al. (2013) with Holstein heifers and Sami et al. (2016) with lambs. While, Shahzad et al. (2011) and Singh et al. (2014) revealed that there were no significant difference in daily gain of buffalo calves consumed rations contained different levels of protein and energy. On the other hand, our results are indicated that all values of daily gain of calves fed either restricted rations or non-restricted one during restricted periods (Table 4) were found to be within the normal range as reported by Afifi (1977) and Metry (1999) who reported that the daily gain of buffalo calves was between 800 to $900 \mathrm{~g} / \mathrm{d}$, depending on the level of concentrates.

Table (4): Daily feed intake, body weight gain and feed conversion during the feed restriction period.

\begin{tabular}{|c|c|c|c|c|c|}
\hline \multirow{2}{*}{ Item } & \multicolumn{5}{|c|}{ Experimental ration } \\
\hline & $\mathrm{T} 1$ & $\mathrm{~T} 2$ & $\mathrm{~T} 3$ & $\mathrm{~T} 4$ & P. value \\
\hline $\begin{array}{l}\text { Daily feed intake as } \\
\mathrm{g} / \mathrm{Kg} \mathrm{W}^{0.75}\end{array}$ & $118.51^{\mathrm{b}} \pm 1.56$ & $120.51^{\mathrm{ab}} \pm 1.36$ & $116.77^{\mathrm{b}} \pm 1.91$ & $124.32^{\mathrm{a}} \pm 1.54$ & 0.02 \\
\hline \multicolumn{6}{|c|}{ Daily feed intake, $(\mathrm{kg} / \mathrm{h} /)$ as DM: } \\
\hline CFM & 2.67 & 1.92 & 0.93 & 0.00 & \\
\hline Berseem hay & 0.39 & 0.46 & 0.51 & 0.64 & \\
\hline Corn silage & 1.67 & 2.28 & 2.76 & 3.12 & \\
\hline R.S. & 1.59 & 1.66 & 1.79 & 2.46 & \\
\hline \multicolumn{6}{|c|}{ Total intake (on DM basis) $(\mathrm{kg} / \mathrm{h} / \mathrm{d})$ as : } \\
\hline DMI & $6.32^{\mathrm{a}}$ & $6.32^{\mathrm{a}}$ & $5.99^{c}$ & $6.22^{b}$ & 0.0001 \\
\hline TDNI & $3.86^{\mathrm{a}}$ & $3.73^{\mathrm{b}}$ & $3.43^{c}$ & $3.34^{\mathrm{d}}$ & 0.0001 \\
\hline DCPI & $440.50^{\mathrm{a}}$ & $373.51^{b}$ & $212.05^{\mathrm{c}}$ & $164.21^{\mathrm{d}}$ & 0.0001 \\
\hline \multicolumn{6}{|l|}{ Body weight gain } \\
\hline Initial weight $(\mathrm{Kg})$ & $122.50 \pm 2.14$ & $120.84 \pm 2.39$ & $124.50 \pm 1.61$ & $124.17 \pm 2.39$ & 0.61 \\
\hline Final weight $(\mathrm{Kg})$ & $282.67^{\mathrm{a}} \pm 2.73$ & $272.17^{\mathrm{a}} \pm 4.28$ & $257.50^{\mathrm{b}} \pm 6.92$ & $245^{\mathrm{b}} \pm 4.28$ & 0.0001 \\
\hline Total gain $(\mathrm{Kg})$ & $160.17^{\mathrm{a}} \pm 2.46$ & $151.34^{\mathrm{a}} \pm 3.28$ & $133^{\mathrm{b}} \pm 5.66$ & $120.84^{\mathrm{c}} \pm 3.00$ & 0.0001 \\
\hline Daily gain $(\mathrm{kg})$ & $1.068^{\mathrm{a}} \pm 0.19$ & $1.009^{\mathrm{a}} \pm 0.02$ & $0.887^{\mathrm{b}} \pm 0.37$ & $0.806^{\mathrm{c}} \pm 0.02$ & 0.0001 \\
\hline \multicolumn{6}{|l|}{ Feed conversion : } \\
\hline $\mathrm{Kg} \mathrm{DM} / \mathrm{Kg}$ gain & $5.92^{\mathrm{d}}$ & $6.26^{\mathrm{c}}$ & $6.75^{b}$ & $7.72^{\mathrm{a}}$ & 0.0001 \\
\hline $\mathrm{Kg} \mathrm{TDN} / \mathrm{kg}$ gain & $3.61^{\mathrm{d}}$ & $3.70^{\mathrm{c}}$ & $3.87^{b}$ & $4.14^{\mathrm{a}}$ & 0.0001 \\
\hline $\mathrm{Kg}$ DCP/kg gain & $412.46^{\mathrm{a}}$ & $370.18^{\mathrm{b}}$ & $239.06^{\mathrm{c}}$ & $203.73^{\mathrm{d}}$ & 0.0001 \\
\hline
\end{tabular}

$a, b$ and $c$ means bearing different superscripts on the same row are significantly different $(p<0.05)$ 
Concerning results of feed conversion that expressed $\mathrm{kg}$ DM, TDN and DCP per kg gain during the restricted period are summarized in Table (4). During the restricted period, the feed conversion (Kg DM/Kg gain) improved as the level of CFM increased in the rations. Calves fed roughage alone T4 was significantly $(\mathrm{P}<0.05)$ higher in feed conversion respecting $\mathrm{kg}$ DM or TDN per kg gain in comparison with calves fed other restricted rations (T2 and T3) and non- restricted ration (T1). Moreover, it was clearly that all calves fed restricted rations caused a marked increased in feed conversion $\mathrm{kg}$ DM/per $\mathrm{kg}$ gain by 5.74, 14.02 and $30.41 \%$, for T2, T3 and T4, rations, respectively in comparison to control one. Moreover, the best feed conversion value was observed with calves fed the non-restricted (T1) and the poorest one was obtained with calves fed roughage alone (T4). Improvement in feed conversion as $\mathrm{kg}$ DM and $\mathrm{kg}$ TDN / $\mathrm{kg}$ gain in calves fed T1 rations likely due to the improvement in OM digestibility and consequently the more efficient use of the metabolizable energy than those fed the restricted one (T4) that fed roughage alone. In contrast, the depression in feed conversion with calves fed restricted ration (T4) could be attributed to the higher CF content and lower digestibility of OM than those fed the other restricted rations and control one. These findings are in agreement with those obtained by Sayed (2009), Gaafar et al. (2009), Neto et al. (2011), Adeleye et al. (2011), Abbasi et al. (2012) and Malisetty et al. (2014), who concluded that feed conversion improved with increasing energy level in the diets. Results here are in contrary with those obtained by Sami et al. (2016) who found that Najdi lambs fed restricted ration ( $20 \%$ of control ration) significantly $(\mathrm{P}<0.05)$ higher than those fed restricted ration ( $40 \%$ of control group), but no significant different with lambs fed ad libtium (control ration). However, during restricted and re-alimentation periods, Anjum et al. (2013) who recorded that feed conversion as (DM/gain) did not differ with buffalo heifers fed energy restricted ration and energy unrestricted one. Concerning DCP conversion, calves fed tested ration T4 in Table (4) had the best value in respect of $\mathrm{kg}$ DCP : $\mathrm{kg}$ gain in comparison with control (T1) or the other tested ones (T2 and T3). These data are in harmony with those of Shahzad et al. (2011) and Singh et al. (2014) when buffalo calves male or female fed diets contained different protein and energy levels.

\section{During re-alimentation period:}

Concerning results of the average feed intake, body weight gain and feed conversion during realimentation period are presented in Table (5). Data showed that daily DM intake expressed as $\mathrm{Kg} / 100 \mathrm{~kg}$ $\mathrm{BW}$ or as $\mathrm{g} / \mathrm{Kg} \mathrm{W}^{0.75}$ did not significant differences among all experimental rations. Otherwise, results indicated that the daily feed intake of DM, TDN and DCP $(\mathrm{kg} / \mathrm{h} / \mathrm{d})$ were significantly $(\mathrm{P}<0.05)$ lower with all re-alimented calves fed rations (T2, T3 and T4) than that of control one (T1). Furthermore, re-alimented calves fed ration (T4) recorded the lower feed intake of DM, TDN and DCP $(\mathrm{kg} / \mathrm{h} / \mathrm{d})$ in comparison with other restricted rations. These results are in close agreement with those obtained by Mostafa et al. (1993) who found the same trend of total dry matter intake among dietary treatments during the re-alimentation period with Friesian calves those fed previously during the feed restriction phase on forage alone at ad libitum or supplemented with 1 or $1.5 \%$ concentrate feed mixture. Also, similar results are reported by Abouheif et al. (2013) who found that DMI was insignificant decreased during the re-alimentation phase (all treatment group fed ad libitum level) that preceded by restriction phase for growing lambs which fed ad libitum level (control) or restricted feed either 0.75 or 0.60 of ad libitum intake. Additionally, Dashtizadch et al. (2008) revealed that restricted goats that consumed 13\% less feed during feed restriction period and $2 \%$ more feed during re-alimentation period in comparison with control group, being upon re-alimentation, there was a $60 \%$ improvement in the overall feed conversion ratio of the 75-days restricted goats compared with their control goats. Moreover, Kamalzadeh et al. (1997) concluded that lambs subjected to a considerable period of feed quality restriction achieve the same weight as control (unrestricted ones) with significantly lower total feed consumption. Some previous studies suggested improved growth performance during the realimented period was because of increased appetite and feed intake (Marais et al., 1991), but other (Ryan et al., 1993 and Keogh et al., 2015) hypothesized that reduced maintenance requirements and greater deposition of protein were responsible for compensatory growth during the initial stages of re-alimentation, and compensatory growth in the latter stages was attributed to greater DMI. Yet compensatory growth following re-alimentation of nutrients has been reported in sheep with lower feed intake (Kamalzadeh et al. 1997). In contrast, (Greeff et al., 1986, Ryan et al., 1993 and Homem et al., 2007), who showed that feed intake was higher after feed restriction period compared with unrestricted one. Moreover, increase in voluntary feed of re-alimented animals during re - alimentation period (Hornick et al., 2000 and Adeleye et al., 2011) could be attributed to increases in size of the digestive tract, energy and protein requirements for maintenance and modification of the endocrine system. 
Regarding growth performance during the re-alimentation period, total gain and daily gain values were significant $(\mathrm{P}<0.05)$ increased for all restricted groups $\mathrm{T} 2, \mathrm{~T} 3$ and $\mathrm{T} 4$ in comparison with control one, being the highest value was associated with $\mathrm{T} 4$ treatment that have nothing of concentrate (severely feed restricted one), where its ration only consisted of three types of roughage (CS, BH and TRS) during the restriction phase. There were no significant differences among the restriction rations in respect of total gain or daily of calves. The present results are in close agreement with the findings obtained by Mostafa et al. (1993) who fed Friesian calves on ad libitum green forage alone or supplemented with concentrates either $1 \%$ or $1.5 \%$ of their body weight during the restricted phase that followed by energy ration of concentrates and rice straw during the re-alimentation phase for all calves' groups. Also, on line with the results here Kamalzadeh et al. (1997) demonstrated that the delay in growth rate of growing sheep after feed restriction was compensatory during re-alimentation feeding period in despite of the lower total feed consumption. The same authors added that lambs subjected to a considerable period of feed quality restriction achieve the same weight as controls with significantly lower total feed consumption as well. Additionally, on much explicitly, the average daily gain of $36 \mathrm{~kg}$-lambs fed 0.75 and 0.60 of ad libitum intakes were 20 and $3.8 \%$ faster than those of the ad libitum fed group, respectively (Abouheif et al., 2013). However, this superior gain might not be attributed to DMI because intake values were not different $(\mathrm{P}<0.05)$ between restricted and ad libitum groups, but possibility due to the better feed efficiency of the re-alimented lambs and /or decreased heat production during the restriction and its continuation during re-alimentation (Ryan et al., 1993 and Yambayamba et al,. 1996). These results are in agreement with those of Turgeon et al. (1986), but not with those of Greeff et al., (1986) and Homem et al., (2007) who reported that rapid gain during re-alimentation period was associated with increased feed intake. The apparent inconsistency may be interpreted by the differences in restriction levels, composition and quality of the diets, the periods of restriction and realimentation, and physiological age and time that restriction started (Hornick et al., 2000). On the other hand, Addah et al. (2017) concluded that upon re-alimentation, average daily gain and feed efficiency of sheep re-alimented with high protein ration were greater than those with high energy-ration. Yet the realimentation of protein compared with energy was more effective in inducing compensatory growth and improving the carcass weight sheep. It appears that the mechanisms associated with compensatory growth may be related more to improved efficiency of feed utilization during re-alimentation phase than to increased feed intake

Table (5): Daily feed intake, body weight gain and feed conversion throughout the re-alimentation period.

\begin{tabular}{|c|c|c|c|c|c|}
\hline \multirow{2}{*}{ Item } & \multicolumn{4}{|c|}{ Experimental ration } & \multirow[b]{2}{*}{ P. value } \\
\hline & T1 & $\mathrm{T} 2$ & T3 & $\mathrm{T} 4$ & \\
\hline Duration (day) & 90 & 90 & 90 & 90 & \\
\hline \multicolumn{6}{|l|}{ Daily feed intake as: } \\
\hline $\mathrm{Kg} / 100 \mathrm{~kg} \mathrm{B.W}$ & $3.16 \pm 0.03$ & $3.16 \pm 0.04$ & $3.17 \pm 0.05$ & $3.16 \pm 0.03$ & 0.1 \\
\hline $\mathrm{g} / \mathrm{Kg} \mathrm{W}^{0.75}$ & $134.81 \pm 0.99$ & $134.80 \pm 1.12$ & $133.06 \pm 2.17$ & $132.95 \pm 1.07$ & 0.7 \\
\hline \multicolumn{6}{|c|}{ Daily feed intake, $(\mathrm{kg} / \mathrm{h} /)$ as DM: } \\
\hline CFM & 7.52 & 7.43 & 7.08 & 6.83 & \\
\hline R.S. & 2.98 & 2.94 & 2.81 & 2.71 & \\
\hline \multicolumn{6}{|c|}{ Total intake (on DM basis) $(\mathrm{kg} / \mathrm{h} / \mathrm{d})$ : } \\
\hline DMI & $10.50^{\mathrm{a}}$ & $10.37^{\mathrm{b}}$ & $9.89^{c}$ & $9.54^{\mathrm{d}}$ & 0.0001 \\
\hline TDNI & $6.83^{\mathrm{a}}$ & $6.75^{\mathrm{b}}$ & $6.44^{\mathrm{c}}$ & $6.21^{\mathrm{d}}$ & 0.0001 \\
\hline .DCPI & $1047.88^{\mathrm{a}}$ & $1034.93^{\mathrm{b}}$ & $987.02^{c}$ & $952.09^{\mathrm{d}}$ & 0.0001 \\
\hline \multicolumn{6}{|l|}{ Body weight gain } \\
\hline Initial weight $(\mathrm{Kg})$ & $282.67^{\mathrm{a}} \pm 2.73$ & $272.17^{\mathrm{a}} \pm 4.28$ & $257.50^{\mathrm{b}} \pm 6.92$ & $245 \pm 4.28^{b}$ & 0.0001 \\
\hline Final weight $(\mathrm{Kg})$ & $382.84^{\mathrm{a}} \pm 3.44$ & $385.17^{\mathrm{a}} \pm 3.44$ & $368.84^{\mathrm{b}} \pm 6.55$ & $359.50^{\mathrm{b}} \pm 3.76$ & 0.001 \\
\hline Total gain $(\mathrm{Kg})$ & $100.17^{\mathrm{b}} \pm 1.51$ & $113.00^{\mathrm{a}} \pm 1.81$ & $111.34^{\mathrm{a}} \pm 0.80$ & $114.50^{\mathrm{a}} \pm 0.67$ & 0.0001 \\
\hline Daily gain (kg) & $1.113^{\mathrm{b}} \pm 0.03$ & $1.256^{\mathrm{a}} \pm 0.02$ & $1.237^{\mathrm{a}} \pm 0.001$ & $1.274^{\mathrm{a}} \pm 0.008$ & 0.0003 \\
\hline \multicolumn{6}{|l|}{ Feed conversion: } \\
\hline $\mathrm{Kg} \mathrm{DM} / \mathrm{Kg}$ gain & $9.43^{\mathrm{a}}$ & $8.26^{\mathrm{b}}$ & $8.00^{c}$ & $7.49^{\mathrm{d}}$ & 0.0001 \\
\hline $\mathrm{Kg}$ TDN/kg gain & $6.14^{\mathrm{a}}$ & $5.37^{\mathrm{b}}$ & $5.21^{\mathrm{c}}$ & $4.87^{\mathrm{d}}$ & 0.0001 \\
\hline $\mathrm{Kg}$ DCP/kg gain & $941.49^{\mathrm{a}}$ & $823.99^{\mathrm{b}}$ & $797.91^{\mathrm{c}}$ & $747.32^{\mathrm{d}}$ & 0.0001 \\
\hline
\end{tabular}


Concerning the results of feed conversion that estimated during the feed re -alimentation period, it could be showed that the feed conversion in terms of $\mathrm{kg}$ DM, TDN and DCP per $\mathrm{kg}$ gain was significantly $(\mathrm{P}<0.05)$ improved with the all re-alimented calves fed rations $(\mathrm{T} 2, \mathrm{~T} 3$ and $\mathrm{T} 4)$ than non- re-alimented ones whose have received the unrestricted ration during the restriction phase (T1). Moreover, the feed conversion seemed to be more efficient with calves fed re-alimented ration T4 compared with other re-alimented rations (T2 and T3). Extensive studies in ruminant animals have shown that a range of variability in rate of catch up growth that might be influenced by genetic factors, the severity and duration of restriction, the quality of re-alimentation diet and duration of re-feeding (Lawrennce and Fowler, 2002). Excessively, the present results are in close agreement with those recorded by Mostafa et al. (1993) who used Friesian calves in feeding on ad - libitum sorghum forage supplemented with concentrate mixture $0.0,1.0$ or $1.5 \%$ of their live boy weight during 120-d restriction period. Also, similar results are achieved by Abouheif et al. (2013) who found after re-feeding the $30 \mathrm{~kg}$ - lambs feed efficiency (gain : DMI) was slightly improved by 4.2 and $10.9 \%$ for the 0.75 and 0.60 of ad-libitum groups and by 22.6 and $53.5 \%(\mathrm{P}<0.01)$ for the $36-\mathrm{kg}$-lambs, respectively compared with lambs fed ad-libitum. Moreover, with young male goats, Dashtizadch et al. (2008) demonstrated that upon re-alimentation phase, there was a $60 \%$ improvement in the overall feed conversion ratio of the 75-d restricted goats compared with their control ones. Similarly, Sami et al (2016) observed that Najdi lambs fed restricted ration significantly $(\mathrm{P}<0.05)$ better in feed efficiency in comparison with control group. Moreover, Sainz et al. (1995) and Keogh et al. (2015) they reported that improved feed conversion has point out to be related to compensatory growth. Generally, enhancement of in several studies (Turgeon et al., 1986, Ryan, 1990, Kamalzadeh et al., 1997, Hossain et al., 2003 and Homem et al., 2007). In contrast results here are disagreed with those obtained by Adeleye et al. (2011) indicated that feed conversion was lowest of rams feeding restricted than those of control group during re-alimentation period. While, Anjum et al. (2013) point out that there were no differences between energy re-alimented and non-realimented in feed conversion during re-alimentation period.

\section{During whole periods:}

Results of the average feed intake, total body daily weight gain and feed conversion during the whole period are summarized in Table 6 . The daily DM intake expressed as $\mathrm{Kg} / 100 \mathrm{~kg}$ B.W was insignificantly differences among all groups. While, the daily DM intake expressed as $\mathrm{g} / \mathrm{Kg} \mathrm{W}^{0.75}$ was significantly $(\mathrm{P}<0.05)$ higher with calves fed restricted rations (T4 and T3) compared with those fed the other experimental rations (T1 and $\mathrm{T} 2)$. On the other hand, the daily feed intake $(\mathrm{kg} / \mathrm{h})$ that expressed as $\mathrm{DM}$, TDN and DCP of calves during whole period were slightly declined with the restriction rations (T2, T3 and T4) than those unrestricted one (T1), however the differences being statistically significant between them. These results are in consistent with those obtained by Mostafa et al. (1993) who used Friesian calves in a growth -fattening trial where they were fed over feed restriction period on sorghum forage at ad libitum level with different levels of concentrates supplementation $(0.0,1.0$ and $1.5 \%)$ of live body weight of calves. Also, Sami et al. (2016) found that lambs fed restricted rations (20\% and 40\% of control ration) were significantly $(\mathrm{P}<0.05)$ decreased DMI than that fed control ration. In contrary, during the whole period Anjum et al. (2013) reported that insignificant difference in DMI between growing buffalo heifer fed restricted energy than that of control group.

During the whole experimental period (240-d), feed conversion values in terms of kg DM, TDN, and DCP per kg gain were the best with calves fed restricted ration (T2) than those fed restricted rations (T3 and T4) and unrestricted ration (T1). These results are in close agreement with those results of Anjum et al. (2013) who showed that growing buffalo heifers on fed restricted energy diet was improved feed efficiency than in unrestricted one overall the experimental period. While, Sami et al. (2016) indicated that there was insignificant differences in average daily gain among groups (restricted rations and control ration). Also, nonsignificant effect on feed conversion was earlier found by Mostafa et al. (1993) who fed growing fattening calves on ad libitum sorghum forage plus $0.0,1.0$ and $1.5 \%$ concentrate over the entire experimental period. Other wish earlier, Murphy and Loerch (1994) found that linear treatment effect $(\mathrm{P}<0.02)$ in respect of gain : feed of steers fed $100 \%$ (ad libitum), 90 or $80 \%$ of ad libitum level, being 0.160 , 0.162 and 0.173 , respectively over the entire period. They were added that the reduction in feed required to finish respectively fed steer led to linear $(\mathrm{P}<0.005)$ improvements in feed efficiency of 1.25 and $8.1 \%$ for the steers with 90 and $80 \%$ of ad libitum intake for the entire feeding period. Definitely, the use of a restricted feeding strategy has the potential to improve carcass composition (reduce excess fat production) without increasing fed cost or sacrificing the efficiency of animal production, 
Table (6): Average daily feed intake, body weight gain and feed conversion throughout the whole experimental period.

\begin{tabular}{|c|c|c|c|c|c|}
\hline \multirow[t]{2}{*}{ Item } & \multicolumn{5}{|c|}{ Experimental rations } \\
\hline & T1 & $\mathrm{T} 2$ & T3 & $\mathrm{T} 4$ & P. value \\
\hline Duration (day) & 240 & 240 & 240 & 240 & \\
\hline $\mathrm{Kg} / 100 \mathrm{~kg} \mathrm{B.W}$ & $3.12 \pm 0.03$ & $3.10 \pm 0.03$ & $3.04 \pm 0.05$ & $3.12 \pm 0.03$ & 0.7 \\
\hline $\mathrm{g} / \mathrm{Kg} \mathrm{W}^{0.75}$ & $90.94^{\mathrm{b}} \pm 0.50$ & $90.08^{\mathrm{b}} \pm 0.59$ & $120.60^{\mathrm{a}} \pm 1.15$ & $121.93^{\mathrm{a}} \pm 1.10$ & 0.0001 \\
\hline \multicolumn{6}{|c|}{ Daily feed intake, $(\mathrm{kg} / \mathrm{h} /)$ as DM: } \\
\hline CFM & 4.48 & 3.99 & 3.24 & 2.56 & \\
\hline Corn silage & 1.04 & 1.42 & 1.72 & 1.94 & \\
\hline Berseem hay & 0.25 & 0.28 & 0.32 & 0.40 & \\
\hline R.S. & 2.12 & 2.14 & 2.22 & 2.56 & \\
\hline \multicolumn{6}{|c|}{ Total intake (on DM basis) $(\mathrm{kg} / \mathrm{h} / \mathrm{d})$ : } \\
\hline DMI & $7.89^{\mathrm{a}}$ & $7.83^{b}$ & $7.50^{\mathrm{c}}$ & $7.46^{\mathrm{d}}$ & 0.0001 \\
\hline TDNI & $5.14^{\mathrm{a}}$ & $5.10^{\mathrm{b}}$ & $4.88^{c}$ & $4.86^{\mathrm{d}}$ & 0.0001 \\
\hline DCPI & $787.42^{\mathrm{a}}$ & $781.43^{b}$ & $748.50^{\mathrm{c}}$ & $744.51^{\mathrm{d}}$ & 0.0001 \\
\hline \multicolumn{6}{|l|}{ Body weight gain } \\
\hline Initial weight (Kg) & $122.50 \pm 2.14$ & $120.84 \pm 2.39$ & $124.50 \pm 1.61$ & $124.17 \pm 2.39$ & 0.61 \\
\hline Final weight $(\mathrm{Kg})$ & $382.84^{\mathrm{a}} \pm 3.21$ & $385.17^{\mathrm{a}} \pm 3.44$ & $368.84^{\mathrm{b}} \pm 6.55$ & $359.50^{\mathrm{b}} \pm 3.76$ & 0.0001 \\
\hline Total gain $(\mathrm{Kg})$ & $260.34^{\mathrm{a}} \pm 2.46$ & $264.34^{\mathrm{a}} \pm 1.80$ & $244.34^{\mathrm{b}} \pm 5.34$ & $235.34^{\mathrm{b}} \pm 2.67$ & 0.0001 \\
\hline Daily gain (kg) & $1.085^{\mathrm{a}} \pm 0.01$ & $1.100^{\mathrm{a}} \pm 0.009$ & $1.018^{\mathrm{b}} \pm 0.02$ & $0.980^{\mathrm{b}} \pm 0.01$ & 0.0001 \\
\hline \multicolumn{6}{|l|}{ Feed conversion : } \\
\hline $\mathrm{Kg}$ DM/ Kg gain & $7.27^{\mathrm{c}}$ & $7.12^{\mathrm{d}}$ & $7.37^{\mathrm{b}}$ & $7.61^{\mathrm{a}}$ & 0.0001 \\
\hline $\mathrm{Kg} \mathrm{TDN} / \mathrm{kg}$ gain & $4.74^{\mathrm{c}}$ & $4.64^{\mathrm{d}}$ & $4.79^{\mathrm{b}}$ & $4.96^{\mathrm{a}}$ & 0.0001 \\
\hline $\mathrm{Kg}$ DCP/kg gain & $725.73^{c}$ & $710.39^{d}$ & $735.27^{\mathrm{b}}$ & $759.70^{\mathrm{a}}$ & 0.0001 \\
\hline
\end{tabular}

$a, b$ and $c$ means bearing different superscripts on the same row are significantly different $(p<0.05)$.

\section{Blood parameters:}

Data of some blood serum parameters during the restricted period are presented in Table (7). Total protein, albumin and globulin concentrations were significant $(\mathrm{P}<0.05)$ lower with all restricted rations than those of control one. This might be attributed to the wide variation of CP content in the experimental rations being 11.65, 10.25, 8.96 and 7.67\% for rations T1,T2, T3 and T4, respectively (Table 1). Similar results on Baladi heifers were recorded by Ali et al. (2014) who explained that the decreased serum TP concentration in heifers fed low energy and protein may be due to the lower in feed nitrogen intake. Moreover, Ibrahim et

Table (7): Some serum blood constituents of calves buffalo fed on the experimental rations.

\begin{tabular}{lcccccc}
\hline Experimental & \multicolumn{5}{c}{ Item } \\
\cline { 2 - 7 } ration & $\begin{array}{c}\text { Total protein } \\
(\mathrm{g} / \mathrm{dl})\end{array}$ & $\begin{array}{c}\text { Albumin } \\
(\mathrm{g} / \mathrm{dl})\end{array}$ & $\begin{array}{c}\text { Globulin } \\
(\mathrm{g} / \mathrm{dl})\end{array}$ & Al/ Gl ratio & ALT (Iu/L) & AST (Iu/L) \\
\hline The restriction period: & $8.35 \mathrm{a} \pm 0.04$ & $4.75 \mathrm{a} \pm 0.03$ & $3.60 \mathrm{a} \pm 0.06$ & $1.32 \mathrm{a} \pm 0.02$ & $17.12 \pm 0.22$ & $29.73 \pm 2.11$ \\
T1 & $8.01 \mathrm{~b} \pm 0.10$ & $4.45 \mathrm{~b} \pm 0.05$ & $3.56 \mathrm{ab} \pm 0.03$ & $1.25 \mathrm{ab} \pm 0.06$ & $17.55 \pm 0.25$ & $30.03 \pm 1.95$ \\
T2 & $7.40 \mathrm{c} \pm 0.02$ & $3.98 \mathrm{c} \pm 0.04$ & $3.42 \mathrm{~b} \pm 0.6$ & $1.16 \mathrm{ab} \pm 0.08$ & $17.45 \pm 0.55$ & $32.05 \pm 1.25$ \\
T3 & $6.29 \mathrm{~d} \pm 0.02$ & $3.25 \mathrm{~d} \pm 0.02$ & $3.04 \mathrm{c} \pm 0.5$ & $1.07 \mathrm{~b} \pm 0.03$ & $17.77 \pm 0.15$ & $35.23 \pm 2.01$ \\
T4 & 0.0001 & 0.0001 & 0.0001 & 0.0001 & 0.15 & 0.75 \\
P. value & 8.54 & 4.87 & 3.67 & 1.33 & 18.80 & 33.45 \\
The re-alimentation period. & & & & & \\
Exp. Ration & & & & & & \\
\hline
\end{tabular}

$a, b$ and $c$ means the same column with different superscripts differ $(P<0.05)$. 
al. (2005) recorded that serum globulin concentration was significantly $(\mathrm{P}<0.05)$ higher with calves fed high of TDN and DCP than those fed the lower ones. In this items, while, the serum A/G ratio, was significant $(\mathrm{P}<0.05)$ lower with calves fed restricted ration $(\mathrm{T} 2, \mathrm{~T} 3$ and $\mathrm{T} 4)$ in comparison with unrestricted one $(\mathrm{T} 1)$, but there were no significant differences among all calves fed restricted rations (T2, T3 and T4). Also, Cole (2000) reported that the decreased feed intake for a certain period can result in alterations nutrient serum concentrations. In contrast, Singh et al. (2014) indicated that blood metabolism did not affect with calves under different levels of protein and energy (urea, glucose and protein)). On the other hand, results indicated that insignificant differences among groups in ALT and AST were observed. These results are similar with those found with Guzerá female Neto et al. (2011). All blood parameters (respecting the restricted and realimentation periods) found to be within the normal range as reported by (El -Kaneko et al., 1997).

\section{Economic efficiency}

Data of the economical evaluation during the whole experimental period (240 days) are presented in Table 8. Data showed that feed cost per Kg gain was LE. 20.35, 19.11, 16.88 and 14.68 for rations $\mathrm{T} 1, \mathrm{~T} 2$, $\mathrm{T} 3$ and T4, respectively. Moreover, fed restricted rations caused a reduction in the feed cost per $\mathrm{kg}$ gain by 7.41, 11.62. and $26.54 \%$ for rations $\mathrm{T} 2, \mathrm{~T} 3$ and $\mathrm{T} 4$, respectively based on control ration (T1). The corresponding values for economical efficiency were 2.93, 3.17, 3.32 and 3.67, for rations T1, T2, T3 and $\mathrm{T} 4$, respectively being the best efficiency was associated with the restriction rations $\mathrm{T} 2, \mathrm{~T} 3$ and $\mathrm{T} 4$, and also the improvement of economic efficiency $(\%)$ based on control ration (100\%) were 108.19113 .31 and $125.26 \%$ for the restricted ration groups (T2, T3 and T4), respectively. These results are in harmony with those obtained by Anjum et al. (2013) who showed that the feed cost per one kg gain was lower for growing buffalo heifers fed restricted ration in comparison with those fed the control ration. Also, compensatory growth phenomenon can be utilized to reduced feed cost (Clanton et al., 1983, and Lynch et al., 1997). In contrast, Sayed (2009) indicated that lambs fed high-energy diet was recorded the highest values in net revenue and economic feed efficiency than those of medium and low - energy diets in lambs. Also, Abbasi et al. (2012) tested different levels of energy diets with goat kids and they found that medium and high energy diets would be beneficial and economically feasible than low energy diet. In perspective, some earlier study suggested that lambs subject to considerable period of feed quality restriction could be achieve the same weight as control with significantly lower total feed consequently increasing the profitability of production (Kamalzadek et al., 1997). Recently, Abouheif et al. (2013) concluded that feed restriction up to $40 \%$ for a 5 -wk period followed by a 4 -wk period of refeeding is economically feasible and does not effect.

Table (8): Productive performance and economical evaluation of buffalo calves fed experimental rations during the whole experimental period.

\begin{tabular}{lcccc}
\hline Item & \multicolumn{3}{c}{ Experimental rations } \\
\cline { 2 - 4 } & T1 & T2 & T3 & T4 \\
\hline Feed intake as fed: & 4.96 & 4.41 & 3.58 & 2.84 \\
CFM & 3.44 & 4.69 & 5.67 & 6.41 \\
Corn silage & 0.27 & 0.31 & 0.35 & 0.44 \\
Berseem hay & 2.36 & 2.39 & 2.48 & 2.99 \\
Rice straw (R.S) & 59.68 & 60.50 & 55.99 & 53.90 \\
Price of daily gain, L.E & 20.35 & 19.11 & 16.88 & 14.68 \\
Total feed cost (LE/day) & 18.76 & 17.37 & 16.58 & 15.00 \\
Feed cost / kg gain (L.E.) & 39.33 & 41.39 & 39.11 & 39.22 \\
Daily profit, L.E & 2.93 & 3.17 & 3.32 & 3.67 \\
Economic efficiency* & 100 & 108.19 & 113.31 & 125.26 \\
Improvement of economic efficiency (\%) & & &
\end{tabular}

Price of Feedstuffs: 3500 LE/Ton of concentrate feed mixture (CFM) and 550 LE/Ton of corn silage, 1250 LE/Ton berseem hay, 320 LE/Ton of rice straw, and price of live body weight: 55 LE/kg live body weight. *Economic efficiency = money output/money in put.. 


\section{Mostafa et al.}

\section{CONCLUSION}

Based on this study, results indicated that all calves fed restricted rations (T2, T3 and T4) followed by realimented feeding period gave significant better growth performance, daily gain and feed conversion ratio over the re-alimented period, being incidencing the compensatory phenomenon which led to potential positive effect on economical efficiency over the whole period of fattening calves.

\section{REFERENCES}

Abbasi, S.A, M.A. Vighio, S.A. Soomro, A.B. Kachiwal, J.A. Gadahi, and G.L. Wang (2012). Effect of Different Dietary Energy Levels on the Growth Performance of Kamori Goat Kids. IJAVMS, Vol. (6), Issue $6: 473-479$.

Abdou, A. A. (2018). Productive performance of lactating buffaloes fed rations containing some feed additives under summer season in Egypt. J. Anim. and Poultry Prod., Mansoura Univ., Vol. 9 (7): 285 293.

Abdou, R. Ahlam (2011). Effect of energy level on digestion coefficients and performance of ewes during pregnancy and lactation in Southern Sinai. Egypt. J. Nutri. and Feeds 14 (3): 349-358.

Abou Elenin, I.M. Ebtehag, A.A. Abdou, W. Abd Elaziz Riad and M.R.M. Mostafa (2016). Effect of dietary niacin and/or thiamin supplementations on growth fattening performance. Egypt. J. Nut. and Feeds, 19(3): 415-425.

Abouheif, M., A. Al-Owaimer, M. Kraidees, H. Metwally and T. Shafey (2013). Effect of restricted feeding and re-alimentation on feed performance and carcass characteristics of growing lambs. Rev. Bras. Zootec. 42, 95-101.

Addah, W., A. Ayantunde and E.K. Okine (2017). Effects of restricted feeding and re-alimentation of dietary protein or energy on compensatory growth of sheep. South African J. of Anim. Sci., 47 (No. 3)

Adeleye, O.O., O.S. Sowande, T.O. Bawala, M.N. Bemji, B.A. Olayode and A.O. Oni (2011). Effects of feed restriction and re-alimentation on performance and nitrogen utilization in growing west African Dwarf rams J. Agric. Sci., Env. 11(2): 76-89.

Afifi, Y.A. (1977). The effect of using different sources of roughages on carcass traits of buffalo calves. Egypt., J. Anim. Prod., 17: 165-171.

Ainsile, S.J., D.G., Fox and T.G. Perry (1992). Management systems for Holstein steers that utilize alfalfa silage and improve carcass value. J. Amin. Sci., 70:2643.

Ali, M.A.E., A.M. Abdel Hafeez, S.A. Ibrahim and Safaa N. Abdel Azem (2014). The productive and reproductive efficiency of cows Baladi heifers under different levels of nutrition. Egypt., J. Nutr., and Feeds, 17(1) 51-61.

Allen, V.G., J.P. Fontenot, R.F. Kelly and D.R. Notter (1996). Forage system for beef production from conception to slaughter : 111 finishing system. J. Amin. Sci., 74:625.

Anjum, M.I., I.H. Mirza and M. Afzal (2013). Effects of Compensatory Growth Pattern on Growth Rate, Reproduction and Lactation Performance in Stall Fed Buffalo (Bubalus bubalis) Heifers. Inter J. Vet. Sci., 2(4): 128- 132.

AOAC (2000). Association of Official Analytical chemists. Official Methods of Analysis Washington, D, C., USA.

Armstrong, W.D. and C.W. Carr (1964). Physiological chemistry $3^{\text {rd }}$ Ed. P.75. burgess publishing Co. Minneapolis /Minnesota.

Blackburn, H.D., G.D. Sonwder and H. Glimp (1991). Stimulation of lean lamb production system. J. Anim. Sci., 69:115. 
Clanton, D.C., L.E. Jones and M.E. England (1983). Effect of rate and time of gain after weaning on the development of replacement beef heifers. J. Anim. Sci.56:280-285.

Cole, N. A. (2000). Changes in postprandial plasma and extracellular and ruminal fluid volumes in wethers fed or unfed for 72 h. J. Anim. Sci. 78:216-223.

Dashtizadeh, M., M.J. Zamiri, A. Kamalzadeh and A. Kamali (2008). Effect of feed restriction on compensatory growth response of young male goats. Iranian J. of Vet. Res. (9) Iss. 2:109-120.

Doumas, B. (1971). Colorimetric determination of albumin. Clin. Chem. Acta, 31: 87.

Duncan, D.B. (1955). Multiple range and multiple F-test Biometrics,11.1.

El-Ashry, M.A., G.F. Shahin, and T.I. Monayer (2011). Effect of feeding different concentrate : corn silage ratio on: 2- productive and some reproductive performance of pregnant buffalo heifers. Egypt., Nutr., and Feeds 14(2): 159-168.

El-Kaneko, J.J., J.E. Harvey and W.J. Sitelu (1997). Clinical biochemical of domestic animals $5^{\text {th }}$ ed. Harcourt Barce and Company Asia PTE. LTD. 989-899.

Gaafar, H.M.A., A.M.A. Mohi El-Din, M.I. Basiuoni and K.F.A. El-Riedy (2009). Effect of concentrate to roughage ratio and baker's yeast supplementation during hot season on performance of lactating buffaloes. Slovak J. Anim. Sci., 42, (4): 188 - 195.

Ghoniem, A.H., A.A. Abdou, E.A. El-Bltagy, R.I. Moawd and A.A. H. El-Tahan (2017). Effect of supplementation dry yeast or bentonite and their combination as feed additives on growth performance of buffalo calves. Egypt. J. Nutr. and Feeds, 20 (3 ) 443-452.

Greeff, J.C., H.H. Meissner, and C.Z. Roux (1986). The effect of compensatory growth on body composition in sheep. South African J. of Anim. Sci., Vol. (16):162-168.

Hanafy, M.A. (1998). Effect of corn supplementation to forage - based diets on performance of steers. Egypt. J. Nutri., and Feeds, 1:33.

Homem, A.C., A.G. Sobrinho and S. Yamamoto (2007). Ganho compensatório em cordeiras na fase de recria: desempenho e medidas biométricas. Revista Brasileira de Zootecnia, Vol. (36):.111-119.

Hornick, J.L., C. Van Eenaeme, O. Gerard, I. Dufrasne and L. Istasse (2000). Mechanisms of reduced and compensatory growth. Domest Anim. Endocrinal 19: 121-132.

Hossain, M.E., M. Shahjalal, M.J. Khan and M.S. Hasanat (2003). Effect of dietary energy supplementation on feed intake, growth and reproductive performance of goats under grazing condition. Pak. J. Nutr. 2(3):159-163.

Ibrahim, S., A.M. El-Gaafarawy, S.M. El- Sheikh, Hanaa A. El-koussy and S.A. Swiefy (2005). Feeding and meet production related parameters in Baladi. Abundance Baladi and Tarenlase Baladi fattened calves. Proc., $2^{\text {nd }}$ Cont. Anim Prod. Res. Inst. Sakha 27-29 Sep: 107.

Kamalzadeh, A., J. Van Bruchem, W.J. Koops, S. Tamminga and D. Zwart (1997). Feed quality restriction and compensatory growth in growing sheep. Livestock Production Science. 52: 209-217.

Keogh, K., S.M. Waters, A.K. Kelly and D.A. Kenny (2015). Feed restriction and subsequent realimentation in Holstein Friesian bulls: I. Effect on animal performance, muscle, fat, and linear body measurements; and slaughter characteristics. J. Anim. Sci. 93:3578-3589.

Lawrennce, T.L.J. and V.R., Fowler (2002). Growth of farm animals, $2^{\text {nd }}$ Edn., CAB International, Cambridge. PP: 229-254.

Lynch, J.M., G.C. Lamb, B.L. Miller, R.T. Brandt, Jr, R.C. Cochran, and J.E. Minton (1997). Influence of timing of gain on growth and reproductive performance of beef replacement heifers. J. Anim. Sci. 75:1715-1722.

Malisetty, V., R.R. Yerradoddi, N. Devanaboina, M. Mallam and P. Mitta (2014). Effect of feeding sorghum straw based complete rations with different roughage to concentrate ratio on dry matter intake, nutrient utilization, and nitrogen balance in Nellore ram lambs. Trop. Anim., Health Prod 46:759-764. 
Marisis, P.G., H.J. Van der Merwe, and J.E.J. DU Toit (1991). The effect of compensatory growth on feed intake, growth rate, body composition and efficiency of feed utilization in Dorper sheep. South Afri. J. Anim. Sci. 21, 80:88.

Mehrez, A.Z., E.M. Soliman, M.Y. El-Ayek, E.A. Ayouty and M.E. El-Khpoly (2001). Influence of roughage to concentrate ratio and type of roughage on digestibility, some rumen parameters and fiber fractions degradability of tested rations with ruminants. Egypt., J. Nutr. and Feeds 4 (Special issue): 193207.

Metry, G.H. (1999). Studies on selenium and/or vitamin E administration to Egyptian buffalo calves. Effect on growth performance, feed efficiency and blood serum calcium and phosphorus. Mansoura Uni. J. Agric. Sci., 24: 1773-1785.

Mostafa, M.R.M., I.M. Ebtehag, Abou - Elenin, A.A. Abdou, and W. Abd elaziz Riad (2015). Effect of thiamin or niacin supplementation into the rations of growing fattening calves on their productive performance. Egypt. J. Nut., and Feeds 18 (3): 373- 382.

Mostafa, M.R.M., S. EL- Kholy, H.M. Ghanem, and W.H. Abdel-Malik (1993). Productive performance of Friesian calves fed on ad libitum sorghum hybrid forage (Pioneer 1988) with or without concentrate supplementation. J. Agric. Sci., Mansoura Univ.18: 682

Murphy, T.A and S.C. Loerch (I994). Effect of restricted feeding of growing steers on performance, carcass characteristics and composition. J. animal Sci., (72): 2497-2507.

Neto S.G., L.R. Bezerra, A.N. Medeiros, M.A. Ferreira, E.C. Pimenta Filho, E.P. Cândido and R.L. Oliveira (2011). Feed restriction and compensatory growth in Guzerá females. Asian-Aust. J. Anim. Sci., 24(6):791-799.

NRC (2001). Nutrient Requirements of Dairy Cattle. 7th Ed., National Research Council, National Academy Press, Washington, DC, USA.

Reitman, S. and S. Frankel (1957). Colorimetric methods for the determination of serum glutamic oxaloacetic and glutamic - Pyruvate transminases. Amin. J. Clin., Pathol., 28:56.

Ryan, W. J. (1990). Compensatory growth in cattle and sheep. In: Nutrition abstracts and reviews (Series B), 50:653-664.

Ryan, W.J., I.H. Williams and R.J. Moir (1993). Compensatory growth in sheep and cattle. II. Changes in body composition and tissue weights. Aust. J. Agric. Res., 44: 1623-1633.

Sainz, R.D., F. de la Torre and J.W. Oltjen (1995). Compensatory growth and carcass quality in growthrestricted and refeeding beef steers. J. Anim. Sci., 73:2971-2979.

Sami, A., B.A. Al-Selbood and M.A. Abouheif (2016). Impact of short compensatory growth periods on performance, carcass traits, fat deposition, and meat properties of Najdi lambs. Turk J. Vet. Anim. Sci., 40: 744-749.

SAS (2003). SAS User's Guide: Statistics. Version 8.2, SAS Institute Inc., Cary, NC.

Sayed, A.B.N. (2009). Effect of different dietary energy levels on the performance and nutrient digestibility of lambs. Vet., World. 2(11):418-420.

Shahzad M. A, A. Nasir, F. A. Tauqir, M. U. Nisa, M. Sarwar and M. A. Tipu (2011). Effects of feeding different dietary protein and energy levels on the performance of 12-15-month-old buffalo calves. Tropical Anim. Health Production 43: 485- 494.

Singh, S., B.P. Kushwaha, S.B. Maity, K.K. Singh and N. Das (2014). Effect of nutrients level and source on feed intake, nutrients digestibility, rumen profile blood metabolites and growth in Bhadawari buffalo female calves. Indian J. of Anim. Sci., 84 (4): 442-446.

Sowande, O.S., O.A. Martins, Z.F. Salami and L.T. Egbeyale (2012). Effects of method of offering forage and concentrate on growth performance, blood biochemical constituents and carcass characteristics of west African dwarf sheep. J. of Applied Agric. Res. 4(1): 55 - 60

Steingass, H., A. Haas, R. Stetter, T. Jilg and A. Susenbeth (1994). Influence of feeding level on nutrient and energy digestibly in sheep and cattle. Wirtschaflseigene-Futter. 40: 2-3, 215. 
Tauqir, N.A, M.A. Shahzad, M. Nisa, M. Fayyaz, M.A. Tipu and M. Sarwar (2011). Response of growing buffalo calves to various energy and protein concentrations. Livestock Sci., 137: 66-72.

Tumová, E. L. Zita, V. Skrivanová, A. Fucíková, M. Skrivan1 and M. Burešová (2007). Digestibility of nutrients, organ development and blood picture in restricted and ad libitum fed rabbits. Arch. Geflügelk., 71 (1). S. 6-12, ISSN 0003-9098.

Tůmová, E., M. Skřivan, V. Skřivanová and L. Kacerovská (2002). Effect of early feed restriction on growth in broiler chickens, turkeys and rabbits. Czech J. Anim. Sci., 47 (10): 418-428

Tumova, E., V. Skrivanova and M. Skrivan (2003). Effect of restricted feeding time and quantitative restriction in growing rabbits. Arch. Geflügelkde, 67: 182 -190.

Turgeon, O.A., D.R. Brink and S.J. Bartle (1986.). Effects of growth rate and compensatory growth on body composition in lambs. J. of Anim. Sci., Vol. 63:.770-780.

Van Keulen, J. and B.A. Young (1977). Evaluation of acid insoluble ash as natural marker in ruminant digestibility studies. J. Anim. Sci.,44: 2982.

Yagoub, Y.M. and S.A. Babiker (2008). Effect of dietary energy level on growth and carcass characteristics of female goats in Sudan. J. Anim. Sci., 80: 100-115.

Yakubu, A. A.E. Salako and A.O. Ladokun (2007). Effects of feed restriction on performance, carcass yield, relative organ weights and some linear body measurements of weaned rabbits. Pakistan J. Nutri, Vol. (6):391-396.

Yambayamba, E.S.K., M. A. Price and G. R. Foxcroft (1996). Hormonal status, metabolic changes, and resting metabolic rate in beef heifers undergoing compensatory growth. J. Anim. Sci., vol., 7 (1): 57-69. 
محمج رفاعى محمود مصطفى ، على أحمد عبده على ، عحم احمد الثوره ، يوسف حسن حاقظ ، عبد العزبز مصطفى صقر ، عادل فوزى ابراهيم عبد اللطيف و عمرو على الجزيرى على على ، على على

معطج بحوث الإتتاج الحيوانى - مركز البحوث الزراعية - اللاقى - الجيزة - مصر.

اجرى هذه البحث لار اسة ظاهرة النمو التعويضي على الأداء الإنتاجى لعجول الجاموس (النمو وتسمين). حيث تم استخدام 24 عجل

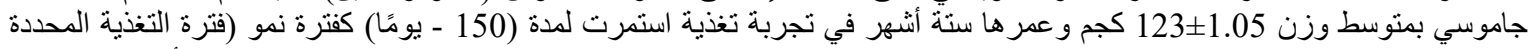

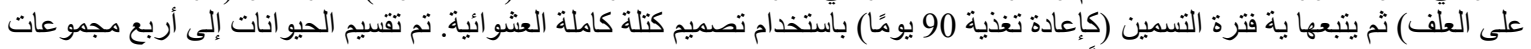

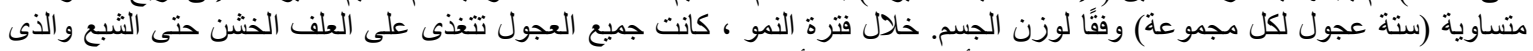

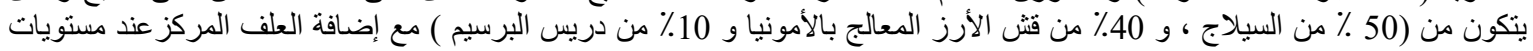

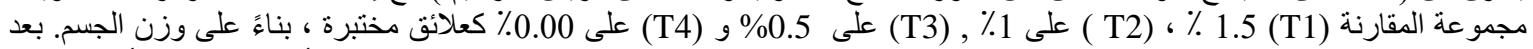

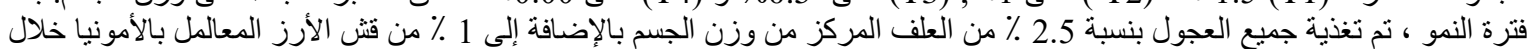

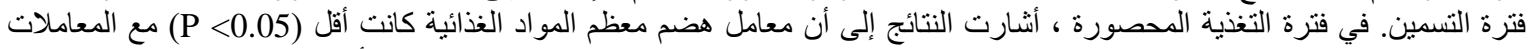

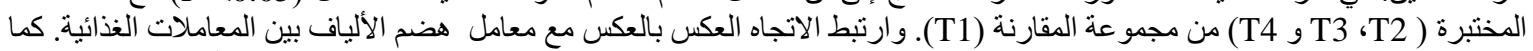



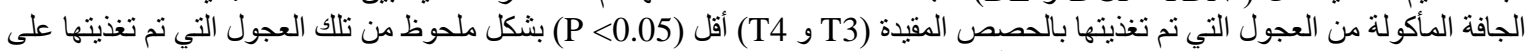

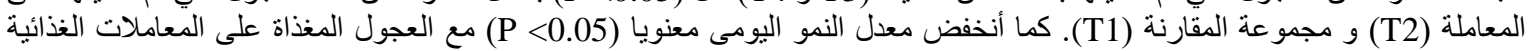

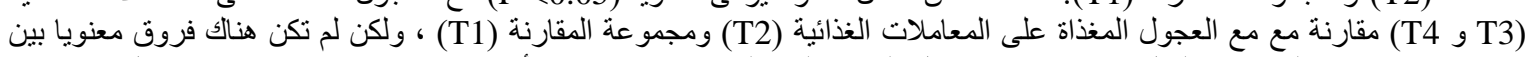

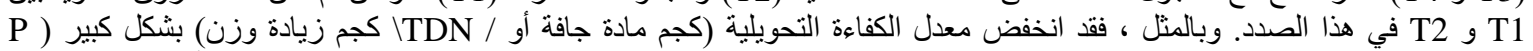

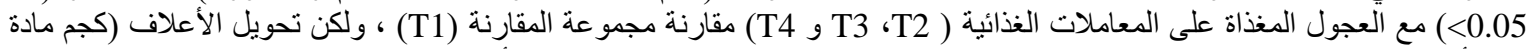

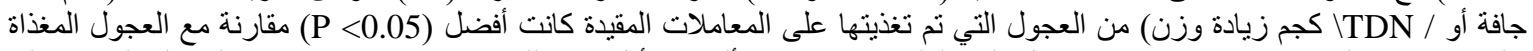

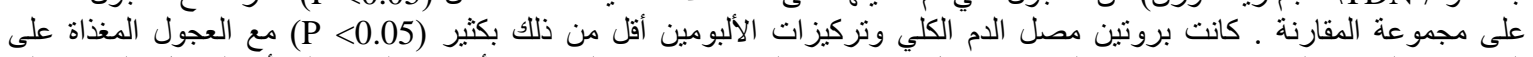

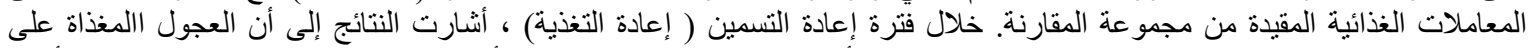

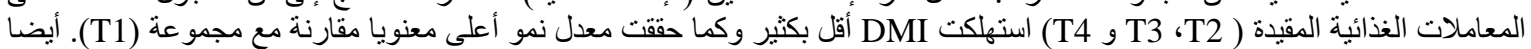

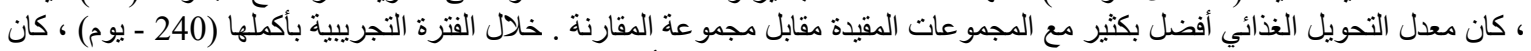

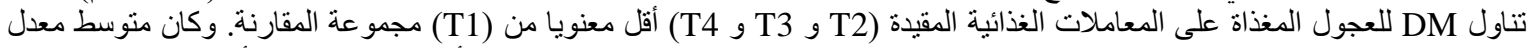

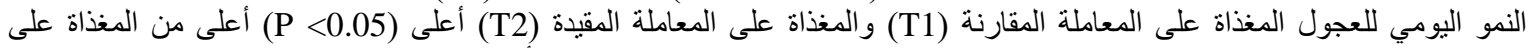

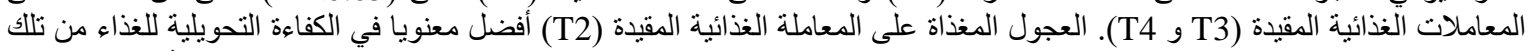

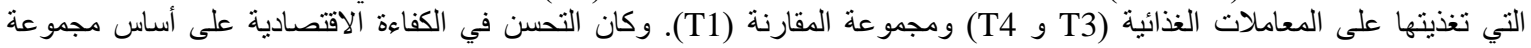

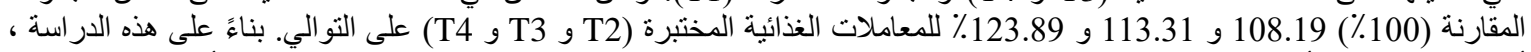

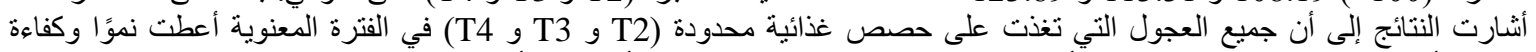

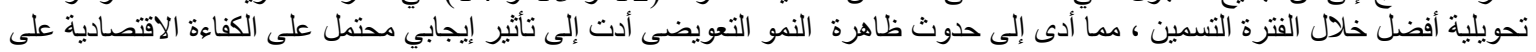
طول فترة تسمين العجول. 